\title{
Women's Work and Economic Change: the Hausa in Sudan and in Nigeria
}

\section{Susan Benson and Mark Duffield}

This paper presents comparative material on the changing nature of women's economic roles amongst two very different Hausa populations: the Hausa residents of Gwagwarwa, an ethnically mixed district within the Kano metropolitan area, northern Nigeria, and the residents of Maiurno, descendants of Hausa and Fulani migrants to Sudan who today form some 10 per cent of the population of that country's northern provinces. ${ }^{1}$ These two populations, widely separated in geographical space, and having access to very different economic opportunities, nevertheless share a common cultural and historical tradition regarding the occupational roles of women. This paper considers the impact on that shared tradition of twentieth century economic changes, especially those wrought by the incorporation of Sudan and Nigeria into a colonial social order and by the expansion of peripheral capitalism.

\section{The context of women's work in Gwagwarwa}

Gwagwarwa lies to the east of the old city of Kano and directly north of Kano's industrial district. In the early years of the colonial period (1903-1930) this was an area of scattered homesteads and small hamlets inhabited by Hausa and Fulani farmers, most of whom also engaged in a variety of dry season, non-farming occupations. Today the descendants of those residents constitute only a tiny fraction of Gwagwarwa's expanded population, which is composed of a variety of ethnic groups: migrants from other areas of the Muslim north; southerners who moved from the over-crowded area of Sabon Gari in Kano after the construction of roads and the installation of public amenities in Gwagwarwa in the middle 1950s; and a variety of peoples from the Niger and Benue-Plateau areas who have largely replaced the Igbos, who, before 1966, formed a significant proportion of the local population (Trevallion 1966). This massive transformation reflects the development of metropolitan Kano as an industrial area within Nigeria second only to Lagos. In the early decades of the colonial

\footnotetext{
1 The analysis that follows is based upon fieldwork carried out by Benson in Kano in 1976 and by Duffield in northern Sudan between 1973 and 1975 , funded by grants northern Sudan between 1973 and 1975 , funded by grants
from the University of Birmingham and the Social Science Research Council respectively.
}

era, Kano's main importance was as a trading centre for agricultural produce, notably groundnuts, and as an exporter of hides and skins (Hogendorn 1966, Okediji 1972). In 1973, the Kano State Commercial and Industrial Handbook recorded 147 manufacturing and processing concerns in the city, many of them privately owned by local entrepreneurs, as well as 460 'small industries', including tailoring, welding, drycleaning, bread production, and so forth.

An inspection of the tax records of three of the four wards that comprise Gwagwarwa demonstrates quite clearly that the area is now structurally as well as geographically part of urban Kano. While a significant number of residents in 1976 described their occupation as farmer, or reported employment in a restricted range of traditional craft and service occupations, most were employed by various local government and state concerns, in local factories, workshops or businesses, as casual labourers, or as suppliers of goods and services in the informal sector of the economy. Tax returns can obviously provide little information on the considerable complexity of combinational employment that is common amongst Hausa men in this area. Nor will they reveal the extent to which men may rely, for part of their subsistence needs, on grain sent to them by kin farming land over which the city-dwellers maintain rights. Nevertheless, such returns do indicate important differences between Hausa and non-Hausa men in the local labour market. In comparison to others, Hausa men are underrepresented in the formal, state-supported sector of the economy as well as in most well-paid artisan occupations, such as welding or electrical or mechanical work. They are correspondingly over-represented in informal sector occupations, especially petty trade. Gwagwarwa is a poor area; the Hausa that live there tend to be the poorer members of the local community. The opportunities available to Hausa women within the local economy must be seen in the context of this relative poverty, and of a division of labour based upon ethnicity as well as gender.

In Gwagwarwa today, it is considered proper for a Hausa woman to have an occupation (sana'a), provided it is one appropriate to her age and social status. Islam as interpreted by the Hausa 
requires that a girl, once she is married in early adolescence, should be secluded. Only when she attains middle age, and has become old (tsohuwa), should she engage in economic activities which take her abroad, although it is recognised that individual husbands may permit their wives greater liberty, that poverty may make it necessary for a married woman to seek employment outside her compound, and that a divorced woman (bazawara) will, broadly speaking, do as she pleases. ${ }^{2}$ As many writers have noted (Smith 1954; Burness 1955, 1957; Cohen 1969; Hill 1969, 1972; Bashir 1972; Simmons 1975; Schildkrout 1978), seclusion is not incompatible with profitable economic activity. In Gwagwarwa as elsewhere in Hausaland, children, older and nonsecluded women, and even husbands, act as intermediaries between secluded women and the market. Thus social differentiation based upon age and relations of personal dependence within the household are an integral part of the Hausa female economy, which may be conceptualised as a developmental cycle in which the opportunities open to women are closely linked to the changing circumstances of their marital and personal careers.

Women's reasons for working, and their perceptions of work itself, are also linked to these changing circumstances. Unmarried girls may work, in a small way, on their own account (Schildkrout 1978), but, in general, they enter the cash economy under the direction of their mothers or female kinswomen, for whom they hawk produce and run errands. In contrast, married women work for themselves; Islam requires that a man maintain his wife and children, and a woman's earnings are therefore hers to keep. Nevertheless, the wives of poor men were, in practice, often prepared to make a substantial contribution to routine household expenses. For such women, work was a matter of straightforward economic necessity, as it was for those other women, widowed or divorced, unable or unwilling to remarry, who were financially responsible for themselves. ${ }^{3}$ For most married women, on the other hand (and it is they who comprise the largest segment of the female workforce), reasons for taking up an occupation tended to be phrased in terms of social rather than strictly economic goals. There are many

2 We are not concerned, in this paper. with courtesanship. karuwanci. which offers an alternative to marriage for adult women.

3 Such women included some of the poorest women in the area. together with some of its most successful female entrepreneurs. The failure to remarry in middle age could thus be either a sign of considerable independence and financial success or the result of an unsuccessful domestic career. things for which women need more money than their husbands can provide: for the purchase of clothing for themselves and their children; the ceremonial exchanges and small gifts which form an important part of women's social relationships with kin and other women; and the purchase of personal household goods, kayan daki (lit.: "goods of the room"), which are an important indicator of female status.

Kayan daki, a collection of brass bowls, decorated enamel plates, pots and pans, china and glass, comprise an important component in a girl's dowry, and remain her personal property throughout life. While successful female entrepreneurs will, and do, spend considerable sums of money adding to their own collection, most women devote their energies to amassing such items for their daughters, for it is the responsibility of the mother, or female guardian, to provide kayan daki for a girl on the occasion of her first marriage. The obligation of a woman to provide kayan daki for the female children of her household is thus central to any understanding of female perceptions of work. On the one hand, it is the cornerstone in the relationship of mutual dependence between adult women and unmarried girls, whose labour is an important element in economic activity for those in seclusion. On the other hand, it commits women to participation in the cash economy, for the goods which comprise kayan daki can be obtained only through the market.

It is important, in this respect, to note the changes in the nature of kayan daki which have taken place since the early years of the colonial era. The matter is somewhat complex and the main issues can only be adumbrated here. Historical evidence, supported by local oral testimony, suggests that, in the first decade of the present century, extensive kayan daki prestations were found only in affluent families. In poorer households kayan daki principally comprised items of local provenance, calabashes and earthenware pots, together with only a small number of brass bowls. ${ }^{4}$ The obligation to provide these items was not onerous. The fall in the price of imported brassware and the increasing availability of decorated enamelware after the completion of the railway to Kano in 1912 , coupled with the increase in money-incomes attendant upon the development of the groundnut economy and the programme of public works instituted by the colonial administration and the Native Authorities, permitted the extension of the tastes of the rich to ordinary households. By the

\footnotetext{
4 See Smith. 1954. pp. 79. 95. A fuller discussion of the historical evidence on this point will be provided in a forthcoming paper.
} 
late 1940s we have reports of kayan daki comprising up to 200 enamel and brass bowls in weddings amongst the prosperous peasantry (Smith 1954: 248; interviews with Hajiya Nana ' $A$ 'isha and Talle, Gwagwarwa, August, 1976). Inflation, however, has rendered the provision of a socially acceptable collection of kayan daki increasingly difficult for women. In 1976 women found themselves having to spend from two hundred up to several thousand Naira on a daughter's dowry, sums which often could be raised only through extensive borrowing. The expansion and elaboration of kayan daki payments may, initially, have been the result of an increased prosperity in which women shared. By 1976, however, it presented women with considerable problems, drawing them into the labour market at no matter what levels of profitability.

A consideration of the changing pattern of Hausa women's work in Gwagwarwa reflects both the changing nature of the local economy and the continuity of experience which mediates women's perceptions and practice of 'work'. In the past, when Gwagwarwa was still, as informants put it, "countryside" (kauye), although unmarried girls helped in the fields, married women did not participate directly in agricultural production. Their principal occupation was the hand-spinning of cotton, either from their husbands' fields or purchased in the market; they also wove cloth on the broad loom, manufactured hats and baskets for sale, and processed groundnuts into oil or cake (kulikuli). In the early years of the colonial era, in contrast to what has been reported for other parts of Hausaland (Smith 1952; Dry 1954; Smith 1954; Hill 1969, 1972, 1977), secluded women did not trade extensively in grain, nor in cooked food: indeed, trade of this sort, which was characterised by informants of both sexes as being of limited provenance prior to the Second World War, was broadly viewed by male respondents in terms of shame, just as occupations such as brokerage (dillanci) or the collection of material for processing or for sale from the bush were stigmatised as appropriate only for the old and the poor.

Women's dependence upon the local textile industry which had flourised in the precolonial period left them vulnerable to the decreasing profitability of that industry (Okediji 1972; Shea 1975). The expansion of demand for imported cloth, the colonial administration's efforts to divert seed cotton from the domestic market to the ginneries of the British Cotton Growing Association and, finally, the establishment of textile mills rendered spinning, never a lucrative occupation, ${ }^{5}$ unrewarding in the urban context. Weaving has been similarly affected. Women's own demand for cloth is now more easily met by profits from some other occupation. Gwagwarwa's population is poor and the area is lacking in the traditional luxury trades, such as the embroidering of saddle-blankets or the manufacture of elaborate sweetmeats, which provide employment for women in the old city. The demand of urban, secluded women for the products of the countryside is met not by Gwagwarwa women but by those of the villages beyond the urban frontier, who bring in groundnut oil, henna and vegetables to hawk around the streets. Nevertheless, material collected in the course of interviews with women in 1976 suggests a considerable degree of continuity in the role of Hausa women in the local economy; today, as in the past, they are principally concerned with the supplying of goods and services, at very low cost, to other Hausa.

Thus, the embroidering of men's caps, the demand for which is of relatively recent origin, has replaced spinning as an occupation which women can perform within the compound in conjunction with their domestic duties. The initial capital required (approximately N.3.00) is small and can be obtained through profits from work requiring no capital at all, such as hairdressing or pounding grain for other women. Alternatively, women can acquire capital as a loan or gift from kin, neighbours or spouse, from savings made from housekeeping money, or from the sale of a cloth or an item of kayan daki. Women have also been able to exploit the greatly expanded local demand for cooked food and snacks. At the time of the Second World War, it became common for elderly, non-secluded women to supply food to the increasing numbers of labourers and artisans coming into the area. In 1976, in every street in Gwagwarwa there could be found numerous compounds, the women of which were engaged in the production of a wide range of foodstuffs. Their greater mobility and freedom to sell outside, rather than from within the compound, ensured that this trade continued to be dominated by women of mature years; nevertheless, younger women, and even those without children in the household old

5 Gowers, writing in 1911, suggested that a spinner in Sokoto, buying her cotton in the market, could expect to make a profit of $1 \mathrm{~s}$. $1 \frac{1}{2} \mathrm{~d}$. On a cloth about seven feet by six and a half feet that she arranged to have woven and then sold to a dyer. To accumulate sufficient thread for a cloth of this size would obviously take some time: in contrast. the weaver would make 4d., plus his meals, for the two day's work needed to weave the cloth The profits the two day's work needed to weave the cloth. The profits Smith 1954, pp. 251-2, for levels of profitability in the late 1940s). 
enough to hawk their wares around the streets, were prepared to set up as food-sellers in the hope of building up a local clientele.

The ideal of seclusion, as has been argued elsewhere (Weeks 1973), undoubtedly restricts Hausa women's participation in the formal sector of the urban economy. Nevertheless, Hausa women were to be found working in Kano's industrial district, in meat canning, in the groundnut industry, and in production of textiles, cosmetics and sweets. Many such women were migrants, often seasonal, from rural areas which had been hit hard by the drought of the early 1970s. Such work, despite its relatively high levels of pay, is, however, stigmatised. Only three of the 42 gainfully employed Hausa women interviewed in 1976 had experience of factory work: one was an independent, divorced woman; one, the wife of a man unable to earn enough to support himself and his family; and the third, an elderly, divorced woman, had been persuaded to leave her factory job by her son, who had provided her with stock to begin trading in canned and packaged goods from the entrance to her house.

For most Hausa women in Gwagwarwa, then, economic activity meant participation in the informal sector of the urban economy. Here, competition was intense and levels of remuneration, in many cases defined by the level of return adequate for a married woman, were low. Pounding grain, hairdressing or weaving provided only a tiny income, as low as N.1.00 a month, and women complained that demand for their services was erratic. A woman embroidering caps could expect to make a profit of between N.3.50 and N.5.00 for between two and four weeks' work. The profits to be made from selling cooked food were more variable, ranging from less than N.4.00 a month to over N.80.00 - the latter, however, in only a small number of cases. In comparison, male wages were high; a young boy, working as an assistant to an operator of a diesel-powered grinding mill, would receive between N.14.00 and N.28.00 a month, while the operator himself would earn double that amount.

In comparison to men, as well as in comparision to non-Hausa women living in the area, Hausa women faced considerable difficulties in capital accumulation, difficulties reflected in the small scale of their operations and their inability to enter any occupation requiring the use of machinery or expensive equipment. Moreover, husbands, who derived no direct benefit from their wives' economic ventures, were understandably reluctant to invest large sums either in lengthy training or in capital equipment for their wives.
Few Hausa women in Gwagwarwa owned sewing machines; and while the larger grinding mills in the area were the monopoly of men, there were no Hausa among the women who had sufficient capital (N.250) to buy one of the smaller machines that could profitably be used to grind other women's oil-seeds, peppers, and beans. The preparation and sale of cooked food on a large scale is arduous for a woman working, as most did, single-handed. Only one Hausa woman in the area could afford to employ paid (as opposed to household) help, and only two retailed food on a sufficient scale to maintain separate rooms for its sale. Significantly, perhaps, both these women, although born in Kano, had spent much of their adult lives outside Hausaland, returning to the city in middle age with sufficient capital to invest not simply in their food businesses, but also in building houses with additional rooms to let.

It was the ambition of many women interviewed eventually to trade - in grain, in canned and packaged goods, or in charcoal and firewood. Yet here they faced competition from men, who were able to trade from more favourable sites, and often had larger amounts of capital which enabled them to buy in bulk and invest in stock attractive to customers. Women themselves often explained the greater success of men in such petty trade by saying that they took more interest in such matters than women. It was certainly true that there was often a self-limiting quality about women's economic activities and that their knowledge of the workings of the local economy was inadequate. This is hardly surprising. For much of their personal careers, women's perceptions of work were defined by their perceptions of their domestic role, and their participation in the local labour market was conditioned by the demands of a female economy, the rationality of which was very different from the rationality of the economy of men. Yet this economy did not exist in isolation; the common denominator of money acted to link the Hausa female economy, in which social goals continue to play a dominant role, to the forces of the wider economic system.

\section{The context of women's work in Maiurno}

The town of Maiumo, situated on the west bank of the Blue Nile about ten miles south of Sennar, lies at the centre of a belt of Nigerian settlement which spans the northern provinces of Sudan. Maiurno itself was founded by a son of Mohammed Attahiru I, Khalif of Sokoto (1902-1903), who, after his father's defeat and death at the hands of the British in 1903, fled eastwards with his followers into Sudan. The history and social 
characteristics of its population thus serve to differentiate Maiurno from the majority of other Nigerian settlements in this area. Most Nigerian migrants, the vast majority of whom arrived in Sudan after 1904, claim for themselves a Hausa, rather than a Fulani, origin, and cite the pilgrimage to Mecca ( $h a j)$ rather than religiously ordained flight from the infidel (hijra) as their reason for leaving Nigeria. At the same time, Maiurno, given its location in an area of considerable post-war rural transformation, reflects many of the wider changes which have affected all communities established by Nigerians in Sudan's northern provinces.

While both Fulani and Hausa settlers give religious reasons for their migration, the growth of Nigerian settlement in Sudan can only be understood within the context of the development of the Sudanese colonial economy. It is important to emphasise that Hausa immigration into Sudan was not an extension of the Hausa trading diaspora (Cohen 1965, 1969; also, Hill 1966; Wilks 1971), but a migration of peasants and labourers. ${ }^{6}$ From the first decade of this century the demand of the colonial administration for labour was acute. Yet not only did Sudan have a relatively small population, but what potential labour force existed was not, up to the 1920s at least, socialised into dependence on wage labour. Hausa immigrants entering Sudan, lacking both homes and land, settled as manual labourers in the towns, as peasant cultivators in the countryside, and, after 1975, as workers on the Gezira cotton scheme. They were generally welcomed by the British and encouraged to settle. Today, Hausa and Fulani immigrants and their descendants, or Takari as they prefer to call themselves, still remain a culturally and structurally discrete segment of Sudanese society, with their own quarters in urban areas and their own settlements in the countryside.

The town of Maiurno, which in 1973 had a population of 14,500 , was, and is, one of the most significant of these rural settlements. At its inception, it was a community of farmers, artisans and keepers of cattle. From the 1920s onwards local farmers have been concerned with the production of cash crops, but until the time of the Second World War the cash thus realised was, for the most part, paid over to the colonial administration as tax, and did not serve as a basis for local capital accumulation. Wage labour existed, but was of limited importance; the predominant form of

\footnotetext{
6 A fuller discussion of this will be provided in Duffield's A fuller discussion of this will be provided in Duffield's
forthcoming Ph.D. dissertation. See also Balamoan 1976,
Birks 1978, Gaitskell 1959, al-Hassan 1977, Hassoun 1952.
}

social relations was that of household production, which centred on the maintenance of paternal authority, through the reproduction of relations of personal dependence within the household.

Over the past 30 years agricultural production in Maiurno has changed profoundly. This change relates not only to the crops produced and the techniques used to produce them, but also to the productive relations which the farmers enter into with each other and with their families. The original impetus for this change does not lie within small-scale peasant agriculture itself, but, as in other areas of Sudan, has come from outside: that is, from the investment of capital which has been accumulated, not in agriculture, but in the commercial and tertiary sectors of the economy which expanded rapidly after the Second World War (Omer 1976, O'Brien 1977). As early as the middle 1940s some of the town's inhabitants had begun to enter the newly expanded commercial sector, especially as lorry drivers, mechanics and tailors: It was these individuals who were able to take advantage of the tenancies available on the three privately owned but government sponsored pump schemes that were set up in 1951, on the edge of the town, to produce cotton. It was commercial capital again, together with profits made on the tenancies in the cotton boom of the immediate post-war years, that permitted some farmers to extend their cultivation of rainland farms, employ hired labour in their cultivation of grains for sale to the expanding urban population, and, finally, in the 1960s, to invest in tractors for ploughing much larger areas than ever before. Maiurno today is characterised by an increasingly important division within the peasantry between those capable of employing labour and those unable to do so, who supply labour to others. The former, who typically combine agricultural activity with some kind of local commercial employment, are able to retain the labour of the members of their household, despite the extension of wage relations into the domestic domain which has occurred in the last $\mathbf{3 0}$ years. The latter, typically dependent entirely upon agriculture, cannot: their sons are to be found working as hired labourers for others, or leave Maiurno altogether to seek employment as apprentices or labourers in the towns along the Blue Nile. The cotton tenancies, which in the 1950s played an important role in generating local capital, have been abandoned by the richer farmers, who now prefer to invest in the transport industry or in local business enterprise; indeed, there is now to be found in the town a sizeable segment of the population which does not farm at all and is entirely dependent upon commerce. 
The collapse of household production and the increasing importance of money in all aspects of economic life have profoundly affected the economic roles of women. Adult women are excluded from agricultural production; on no account would a married woman work in the fields, although some, especially the elderly, plant small vegetable patches within their compounds for domestic use. With the major exception of those settled on the Gezira scheme, this is true of all rural Takari communities, while in urban areas this restriction even extends to unmarried girls. In Maiurno, however, the labour of unmarried girls and of small children is an important element in agricultural production, especially in the sowing, thinning and picking of cotton on the pump schemes. The money earned in this way is supplemented by the gathering of materials from the bush and by small-scale craft activity, and is used by girls to buy clothes, shoes and so forth, as well as items for their dowry.

A striking difference between the economic roles of women in Maiurno and in Gwagwarwa is the absence of Maiurno women from the informal sector of the local economy. Seclusion is normal practice for married women in Maiurno as in Gwagwarwa, but for most production is of a purely domestic nature. Secluded women among the poorer sections of the peasantry prepare and sell a very restricted range of snacks and cooked food and make mats and rope for sale. Among the poor and the elderly, who are not secluded, grainpounding, hairdressing and midwifery, or the manufacture of perfumes, fans and cosmetics offer means of staving off destitution. Among men the decline in women's economic activities, noticeable over the past 30 years, is often explained by the claim that "they have become Arabs". Indeed, there is a growing tendency to associate any kind of economic activity among women with poverty and low status. But economic, as well as cultural, explanations must be taken into account here. The past 30 years have witnessed the steady replacement of goods and services offered by women with, on the one hand, mass-produced products from abroad or from the large towns and, on the other hand, goods and services offered by men. Thus, machine-spun thread has replaced that spun by local women in the market; drinking tea in malerun cafes in the market has replaced the taste for gruels prepared by women; no women in Maiurno sold grain, which was retailed exclusively by merchants in the market to whom peasants frequently mortgaged, their crops. ${ }^{7}$

\footnotetext{
7 This exclusion from all profitable economic activity is not true for all Takari communities in Sudan. In the more
}

The stigma attached to participation in the labour market and the low levels of remuneration accruing therefrom means that, for women at least, the esteemed marriage is one which frees the wife from the necessity of such work. By 1974 girls were prepared to state openly that they no longer wished to marry anyone who did not have a viable occupation within the commercial sector; anything else would, in their opinion, mean a life of poor food and few clothes. Consultation with the prospective bride and the necessity of her agreement to any marriage proposal reflects, perhaps, the relative autonomy of young girls in today's economic conditions. No longer dependent upon their mothers, but independent workers, they perceive their future prospects not, as do the Hausa women of Gwagwarwa, in terms of their own economic activities, but in terms of their husband's occupational opportunities. It is not surprising, therefore, to note that in the past decade the age of marriage for women has risen steadily, so that in Maiurno in 1974 it was not uncommon to find girls of 17 or 18 years still unmarried.

\section{Conclusion}

Shortage of space prevents any lengthy discussion of the issues raised above. Some general points may, however, be presented here. In both cases, that of Gwagwarwa and that of Maiumo, the development, firstly, of the colonial social order, and, secondly, of peripheral capitalism undermined the precolonial basis of the Hausa female economy. In Gwagwarwa, however, we may discern a process of substitution, in which new consumer demands and the expansion of the urban population permitted women to shift from one form of economic activity to others equally compatible with Hausa notions of female propriety. In Maiurno, we discern a process of decay, in which the relations of dependence between adult women and the female children of their household, still of central importance in Gwagwarwa, is being replaced by a new dependence of women upon

\footnotetext{
isolated rural areas of the Takari belt, organised household production for the market is more noticeable among secluded women, perhaps because such communities lack markets which would be profitable enough to attract male traders (see Hill 1969 for the important functions of secluded women traders in rural Hausaland). In urban Takari settlements, unlike in Maiurno, only the wives of the especially pious or the affluent are secluded: in E1 Obeid, for example, Takari women have monopolised gum-cleaning and ground-nut decortication in the town since the early years of the colonial era; they also pound grain and work as domestic servants. Urban Takar women are extensively involved in the trade in cooked food. Through the agency of their daughters, they are the main suppliers of railside of their daughters, they are the main supplers of railside refreshments right across northern Sudan. In short, in urban areas, Takari women, like the women of Gwagwarwa, have been able to take advantage of the expanded opportunities of the informal sector economy - with the important difference that in Sudan, unlike in Nigeria, it is the Takari who have the edge in local competition, albeit for the not especially lucrative opportunities available to women.
} 
their husbands. In both cases, we point to the continuing importance of the institution of marriage in defining women's perceptions of their economic and social roles. In Gwagwarwa, however, women continue to play a vital, though poorly rewarded, part in the local economy. In Maiurno, where capitalist relations of production, in agriculture as well as in commerce, are widespread, they can no longer do so.

\section{References}

Balamoan, G. A., 1976, Migration Policies in the Anglo-Egyptian Sudan 1884-1956, Harvard Centre for Population Studies, Cambridge (Mass)

Bashir, M. K., 1972, The Economic Activities of Secluded Married Women in Kurawa and Lallokin Lemu, Kano City, B.Sc. Thesis, Ahmadu Bello University, Zaria

Birks, J. S., 1978, Across the Savannas to Mecca: the Overland Pilgrimage Route from West Africa, Hurst, London

Burness, H. M., 1955, "The Position of Women in Gwandu and Yauri", Overseas Education, vol. 26

-1975, "Women in Katsina Province, Northern Nigeria", Overseas Education, vol. 29

Cohen, A., 1965, "The Social Organisation of Credit in a West African Cattle Market", Africa, vol. XXXV

-1969, Custom and Politics in Urban Nigeria, Routledge \& Kegan Paul, London

Dry, D. P. L., 1953, The Place of Islam in Hausa Society, D.Phil. thesis, Oxford University

Gaitskell, A., 1959, Gezira: a Story of Development in Sudan, Faber \& Faber, London

Gowers, W. F., 1911, A Note on Trade in Sokoto Province, unpublished ms., Africana collection, Rhodes House Library, Oxford

'al-Hassan, A. M. (ed.), 1977, Essays on the Economy and Society of Sudan, Vol. 1, Khartoum University Press, Khartoum

Hassoun, I. A., 1952, "Westerner Migration and Settlement in the Sudan", Sudan Notes and Records, vol. XXXVII

Hill, P., 1966, "Landlords and Brokers: a West African Trading System', Cahiers d'Etudes Africaines, vol. VI, 23

-1969, "Hidden Trade in Hausaland", Man, vol. 4
-1972, Rural Hausa: a Village and a Setting, Cambridge University Press, Cambridge

-1977, Population, Prosperity and Poverty: Rural Kano 1900 and 1970, Cambridge University Press, Cambridge

Hogendorn, J. S., 1966, The Origins of the Groundnut Trade in Northern Nigeria, Ph.D. Thesis, University of London

O'Brien, J., 1977, “How Traditional is 'Traditional" Agriculture", Economic and Social Research Council Bulletin, No. 62, Khartoum

Omer, H. A. B., 1976, "Rural Traders and SocioEconomic Transformation in Dongola Area, Northern Province", Economic and Social Research Council Bulletin, No. 47, Khartoum

Okediji, F. A., 1972, An Economic History of the Hausa-Fulani Emirates of Northern Nigeria, 1900-1939, Ph.D. Thesis, University of Indiana, Indiana

Shea, P. J. 1975, The Development of an Export Oriented Dyed Cloth Industry in Kano Emirate in the Nineteenth Century, Ph.D. Thesis, University of Wisconsin, Madison

Schildkrout, E., 1978, "Age and Gender in Hausa Society: Socio-Economic Roles of Children in Urban Kano", in J. S. La Fontaine (ed.) Sex and Age as Principles of Social Differentiation, Academic Press, London

Simmons, E. B., 1976, "Economic Research on Women in Rural Development in Northern Nigeria", OLC Paper No. 10, Overseas Liaison Committee, American Council on Education

Smith, M. F., 1954, Baba of Karo: a Woman of the Muslim Hausa, Faber, London

Smith, M. G., 1952, "A Study of Hausa Domestic Economy in Northern Zaria", A frica, vol. XXII

Trevallion, B. A. W., 1966, Metropolitan Kano: Report on the Twenty-Year Development Plan 1963-1983, Greater Kano Planning Authority, Glasgow

Weeks, D. R., 1973, Adaptive Strategies of Men and Women in Zaria, Nigeria: Industrial Workers and Their Wives, Ph.D. Thesis, University of Michigan, Michigan

Wilks, I. G., 1971, "Asante Policy Towards the Hausa Trader in the Nineteenth Century", in C. Meillassoux (ed.), The Development of Indigenous Trade and Markets in West Africa, Oxford University Press, London 